\title{
Spatial and temporal variability of groundwater dynamics in a sub-Mediterranean
}

\section{mountain catchment}

\author{
N. Lana-Renault ${ }^{1}$, D. Regüés ${ }^{2}$, P. Serrano ${ }^{2}$, J. Latron ${ }^{3}$ \\ ${ }^{1}$ Área de Geografía, Departamento de Ciencias Humanas y Sociales, Universidad de La
} Rioja, 26004 Logroño, Spain

${ }^{2}$ Instituto Pirenaico de Ecología, CSIC, Campus de Aula Dei, Apdo. 202, 50080

Zaragoza, Spain

${ }^{3}$ Institut de Diagnosi Ambiental i Estudis de l'Aigua (IDÆA), CSIC, Jordi Girona, 18-

26, 08034 Barcelona, Spain

\begin{abstract}
The temporal and spatial dynamics of groundwater was investigated in a small catchment in the Spanish Pyrenees, which was extensively used for agriculture in the past. Analysis of the water table fluctuations at five locations over a 6-year period demonstrated that the groundwater dynamics had a marked seasonal cycle involving a wetting-up period that commenced with the first autumn rainfall events, a saturation period during winter and spring and a drying-down period from the end of spring until the end of the summer. The length of the saturation period showed great interannual variability, which was mainly influenced by the rainfall and evapotranspiration characteristics. There was marked spatial variability in the water table, especially during the wetting-up period, which could be related to differences in slope and drainage area, geomorphology, soil properties and local topography. Areas contributing to runoff generation were identified within the catchment by field mapping of moisture conditions. Areas contributing to infiltration excess runoff were correlated with former cultivated fields affected by severe sheetwash erosion. Areas contributing to saturation excess runoff were characterized by a marked spatial dynamics associated with catchment wetness conditions. The saturation spatial pattern, which was partially related to the topographic index, was very patchy throughout the catchment, suggesting the influence of other factors associated with past agricultural activities, including changes in local topography and soil properties. The relationship between water table levels and stream flow was weak, especially during thewetting-up period, suggesting little connection between ground water and the hydrological response, at least at some locations. The results suggest that in drier and human-disturbed environments, such as sub-Mediterranean mountains, saturation patterns cannot be represented only by the general topography of the catchment. They also suggest that groundwater storage and runoff is not a succession of steady-state flow conditions, as assumed in most hydrological models.
\end{abstract}

KEY WORDS water table; runoff contributing areas; stream flow; sub-Mediterranean mountain; experimental catchment 


\section{Introduction}

Climate variability and past human disturbances make rainfall-runoff relationships and water-flow pathways in Mediterranean mountains particularly complex and, hence, the hydrological response difficult to predict. Mediterranean areas are characterized by relatively low to moderate annual precipitation and a strong climatic seasonality, with high temperatures and little precipitation in summer contrasting with moderate precipitation and low temperatures in winter. Here, mountains have been markedly affected past human activities (e.g. Arnáez et al., 2011): agricultural practices caused spatial modification of the vegetation cover and soil properties, and the widespread construction of terraces on steep slopes and an artificial drainage networks caused significant topographic changes. Depopulation and progressive land abandonment during the $20^{\text {th }}$ century have led to recovery on an large variety of factors (García-Ruiz and Lana-Renault, 2011) and has resulted in an extraordinary heterogeneous landscape.

Analysis of catchment-scale observational data (e.g., Piñol et al., 1997; Lana-Renault et al., 2007; Latron et al., 2009; Schnabel and Gómez-Gutiérrez, 2013) has revealed that Mediterranean mountains share hydrological processes characteristics of both wet and dry environments. Thus, stream flow response usually results from the combination of contrasting runoff generation processes (infiltration and saturation excess runoff, and subsurface flow), which relative contribution depends on rainfall characteristics, antecedent wetness condition and catchment properties. To be able to explain the nonlinearity of rainfall-runoff in the Mediterranean mountain areas and therefore to improve capability in stream flow prediction, it is necessary to understand the temporal and spatial variability of the water flows within the catchment and relate them to stream flow response. One approach is to analyze the spatial and temporal dynamics of the 
ground water storage (e.g. Seibert et al, 2003; Anderson et al., 2010; Haughts and van Meerveld, 2011). Most of the studies have been carried out in forested humid temperate catchments; surprisingly, few have been undertaken under Mediterranean conditions, where the hydrological processes are particularly complex (e.g. Gaillard et al., 1995; Grésillon and Taha, 1998; Martínez-Fernández et al., 2005; Linde et al., 2007; Latron \& Gallart, 2008).

The aim of this study was to contribute to the understanding of groundwater dynamics and its relations to stream flow in a Mediterranean mountain environment, through the analysis of observational data in a small catchment in the Pyrenees; this catchment was intensively cultivated in the past and affected by land abandonment. We investigated temporal and spatial fluctuations of the water table at various locations within the catchment. The rise of the water table to the soil surface favours the development of water-saturated areas which may contribute to runoff. Thus, we also studied the spatial pattern of saturated runoff contributing areas under various hydrological conditions and analyse the relationship between discharge at the outlet of the catchment and water table response.

\section{Methods: study site and data collection}

\subsection{The catchment}

The Arnás experimental catchment $\left(2.84 \mathrm{~km}^{2}\right)$ is located in the headwaters of the Aragón River (Figure 1a), in the Central Spanish Pyrenees, at an altitude of 910-1340 $\mathrm{m}$ a.s.l. The substratum is Eocene flysch. Soils are dominated by compact and shallow calcaric regosols on the southwest-facing slope (Navas et al., 2008) and brown and deep haplic kastanozems on the northeast-facing slope. The catchment is representative of the mid-altitude Mediterranean mountain environment and land management evolution, as it was totally cultivated with cereal crops in non-terraced fields until the middle of the 
20th century, then abandoned and naturally colonized with shrubs and some forest patches. The mean annual temperature is $10^{\circ} \mathrm{C}$, and mean annual precipitation from 1999 to 2008 was $926 \pm 182 \mathrm{~mm}$. Snowfall occurs only occasionally. The mean annual reference evapotranspiration in the study area calculated by the method of HargreavesSamani (1985) was $1088 \pm 31 \mathrm{~mm}$. Figure 2 shows that rainfall is usually concentrated in autumn (October, November) and spring (March, April, May); winter (December, January, February) is a period having less precipitation and low evapotranspiration; and summer (June, July, August) is a period with very high evapotranspiration and little rainfall - although intense convective storms of short duration are relatively frequent. The combination of rainfall and evapotranspiration over the water year results in a strong water deficit in the summer and beginning of autumn (as evidenced by low levels of runoff), and a wet period in spring, when runoff reaches the highest values. Figure 2 also shows the strong non-linearity of the rainfall-runoff relationship over the water year. This is clearly illustrated in October, when heavy rainfall (similar to that in April) produced only moderate runoff. Here, as in many other Mediterranean areas (Gaillard et al., 1995; Serrano-Muela et al., 2008; Latron et al., 2009), most of the incoming rainfall occurring at the beginning of the water year is used to recharge soil moisture and groundwater reserves.

The catchment is equipped with a complete weather station, a gauging station at the lowest end of the catchment, at which discharge and sediment transport is recorded, and three tipping bucket rain gauges (Figure 1B). A network of five piezometers was installed in downslope locations at different distances from the main channel and in areas where field observations indicated significant saturation dynamics. The depth to the water table is measured in each tube using a Keller DCX-22 AA pressure sensor connected to a datalogger. The water level is measured at 1 min intervals and stored as 
20 min averages. A $10 \times 10 \mathrm{~m}$ Digital Elevation Model of the catchment was constructed using a contour map (contour interval, $5 \mathrm{~m}$ ) obtained from 1:5000-scale aerial photographs. The topographic index $\ln (\mathrm{a} / \tan \beta)$ (Kirkby, 1975) was calculated using the Digital Elevation Model and DiGeM 2.0 software. This study was based on rainfall, discharge and water table data obtained over the 6 water years (October to September) from 2004 to 2009.

Research on the role of saturation excess runoff processes in hydrology (e.g., Cappus, 1960; Dunne \& Black, 1970) gave rise the concept of "variable source area", within a catchment, this refers to particular locations that are most important for runoff generation processes and have an spatial extent that is variable through time. Because these studies were carried out in humid temperate regions, where rainfall intensity is usually lower than soil infiltration capacity, variable source areas were commonly identified as water-saturated areas, usually occurring on down slope locations close to the main stream. Later studies (e.g., Betson \& Marius, 1969; Cosandey \& de Oliveira, 1996) showed that they can occur anywhere in the catchment, according to site specific topographic and soil characteristics. However, as pointed out by Ambroise (2004), only those locations connected to the effective drainage network directly contribute to runoff discharge at the outlet of the catchment and thus should be the ones refer as "runoff contributing areas". In regions where rainfall intensity is higher than soil infiltration capacity, runoff can also be generated by infiltration excess processes (Ambroise, 2004; Latron \& Gallart, 2007) in areas having low permeability soils. This is commonly observed in the Mediterranean region, where rainfalls can be very intense and soils have been significantly degraded by past agricultural practices (Navas et al., 2008).

A good method for studying the spatio-temporal evolution of runoff contributing areas within a small catchment is by field mapping (e.g., Dunne et al., 1975). This 
approach has commonly been used in humid temperate regions (e.g., Dunne et al., 1975; Taylor, 1982; Ambroise, 1986) but rarely under Mediterranean conditions (Martínez-Fernández et al., 2005; Latron \& Gallart, 2007), even though several authors have highlighted the importance of the spatial distribution of runoff contributing areas on catchment hydrological response (e.g., Grésillon \& Taha, 1998; Latron \& Gallart, 2007).

Infiltration excess runoff contributing areas are easily recognizable in the field by inspection of the soil surface (Dunne et al., 1975). Water-saturated areas can also be identified visually using the "boot" method, which involves stepping ont the soil surface and assessing whether water appears (Ambroise, 1986; Latron \& Gallart 2007; Rinderer et al., 2012). The spatial variations of saturated areas can be done by repeat field mapping under differing hydrological conditions. According to Ambroise (1986), if surveys are carried out by the same person, the error associated to such approach is $<10 \%$. In this study, we carried out four field surveys under conditions varying from dry to wet. Each survey was made at least 36 hours after a flood event, to ensure the catchment recovered hydrological equilibrium (Latron \& Gallart, 2007). Accurate mapping of the extent of the saturated areas was possible by using an enlarged orthophotomap of the catchment. Each map was subsequently digitized to quantify the extent of the saturated areas.

\section{Results and discussion}

3.1. Seasonal and spatial variability of the water table dynamics

Groundwater changes followed a clear seasonal pattern that was repeated each water year. This involves: i) a wetting-up period corresponding to a rise in the piezometric levels, which started with the first autumn rainfall events and lasted until the reconstitution of water reserves at the measured locations was complete, ii) a saturation 
period over winter and spring where water table was close to the soil surface at all locations, and iii) a drying-down period with a progressive decline of water-table levels, starting from the end of spring or beginning of the summer. This is illustrated in Figure 3 , which shows the seasonal evolution of the mean daily water table depth measured at the 5 piezometers from March 2005 to September 2009. The evolution of daily rainfall and runoff is also plotted in the upper part of the figure. It is noteworthy that in the water year 2004-2005, the ire of the water table did not start until late spring, and thus the saturated period was very short. This general seasonal pattern has been reported in Mediterranean (Latron et al., 2009) and (to a lesser extent) humid environments (e.g., Peters et al., 2003; Molénat at al., 2005) and is strongly regulated by the combination of rainfall and evapotranspiration demand over the water year. The decline of groundwater reserves was closely associated to the increasing water deficit observed (Figure 2) from the end of spring (May) until the end of the summer (September), which is triggered by a notable increase in evapotranspiration and decrease in rainfall. The filling of catchment reserves is only possible following summer, when rainfall exceeds evapotranspiration. The low evapotranspiration demand during autumn and winter ensures the high water table level, even with low rainfalls levels.

Figure 3 shows that high runoff (i.e. daily runoff $1 \mathrm{~mm} /$ day) only occurred when water table levels was close to the soil surface, highlighting the importance of catchment moisture conditions on the stream flow response, as reported in previous studies (Lana-Renault et al., 2007). As a result of interannual climatic variability, the length of the saturation period was variable among years. Thus, during the water year 2006-2007, the soil was saturated (i.e., water table was within $0.10 \mathrm{~m}$ of the soil surface) for $43 \%$ of the year at location 2 and $66 \%$ at location 8 (table 1) whereas at these locations in the 2004-2005 water year, the soil was saturated only 9 and $16 \%$ of 
the year, respectively. The variability of the length of the saturation period strongly influenced the annual water yield of the catchment. The relationship between annual runoff and rainfall was greatly increased $(\mathrm{R}=0.95, \mathrm{p}<0.05)$ if the rainfall occurring during the saturation period was considered, rather that the total annual rainfall (no significant relationship); this suggests that saturation processes had a major role in runoff generation in this catchment.

The water table dynamics varied markedly among locations. The length of the saturation period varies from $20 \%$ at location 2 to $34 \%$ of the year at location 8 , based on the three years $(2004,2006,2007)$ for with complete water table records at all locations were available. Figure 3 shows that the spatial variability of the water table was greater during the wetting-up and drying down transition periods. For instance, during the drying down period in 2006, a $1.5 \mathrm{~m}$ fall in the water table occurred over 10 days at location w8 and over a period of 1 month at location w9. This spatial variability is illustrated in Figure 4, where the standard deviation (indicative of the degree of variability among locations) was higher for intermediate water table conditions. A comparable seasonal pattern (with wet and dry periods) has been reported elsewhere (e.g., Peters et al., 2003; Molénat at al., 2005); however, the high spatial variability of water table fluctuations, especially during the transition periods, seems to be a more characteristic feature for Mediterranean regions (Latron et al., 2009).

To further investigate the spatial variability of the water table, the relationships between daily water table depths at locations 7,8 and 9 were analyzed; the piezometers at these locations were approximately $2 \mathrm{~m}$ depth and were selected because they dried less frequently during the year. Figure 5 shows that there was only a weak correlation among the water table levels at the three locations. Slightly stronger relationship were observed when only the drying-down periods (white dots in Figure 5) were considered, 
especially between locations 7 and 9 , with piezometer 9 emptying more rapidly than the piezometer at location 7 . The pattern between locations 7 and 8 was not considered, with the piezometer at location 7 sometimes emptying before the piezometer at location 8 , while on other occasion the relationship was reversed. No clear relationships were observed during the wetting-up period (black dots in Figure 5), indicating that the refilling/recharge of groundwater reserves was characterised by greatest spatial heterogeneity. As shown in Figure 3, water table at locations 8 and 9 reacted rapidly to the first rainfall events in autumn, but fell rapidly when the rain stopped, especially at location 8 . This was in contrast to the water table at location 7 , where it rose rapidly following 225-250 $\mathrm{mm}$ of accumulated rainfall and remained saturated until the end of the wet period. Examples of water table not responding homogeneously to rainfall have reported in recent studies in British Columbia (Anderson et al., 2010; Haughts \& Meerveld; 2011) and Sweden (Seibert et al., 2003). These reports showed that variability in the water response was related to the position on the hillslope. Dripps \& Barbuty (2011) also observed a high spatial variability in a forested catchment in Wisconsin and related the differences to vegetation cover. On the contrary, other studies (e.g. Fanning et al., 2000; Bachmair and Weiler, 2012) found out that soil hydraulic properties play a major role in controlling subsurface flow variability. In the Arnás catchment, the vegetation cannot be considered a factor controlling water table fluctuations, as all the piezometers are located under similar vegetation type (grass with few stands of Fraxinus sp). To assess the influence of topography, we investigated the relationships of the averaged percentage of time each piezometer was saturated to the straight distance to the stream and the topographic index. Figure 6a indicates that soil saturation was not influenced by the distance to the main stream. The percentage of time that locations 9 and 4 remained saturated was similar (24\% and 27\%, respectively), 
despite the former is located $50 \mathrm{~m}$ from the main stream whereas the latter is at $220 \mathrm{~m}$ distance. Soil saturation showed a positive relationship with the topographic index at all the locations, except for location 8. This is consistent with the concept of the wetness index (Kirkby, 1975; O’Loughlin, 1981) and suggests a strong topographic control of saturation patterns. The highest values of the topographic index $(>10)$ were found at locations 4 and 7, both situated in relatively flat areas of the gentle north-facing slope that are saturated for approximately one-third of the time. Location 8 was somewhat unusual in that the piezometer data indicated it was the site that was most often saturated $(34 \%$ of the time) but has a low topographic index $(<8)$. Differences in lithology, soils properties (infiltration capacity and the occurrence of macropores) or local topography have been usually reported as factors which can modify saturation dynamics at specific sites. In our study, one explanation for the observed results is that piezometer 8 was located close to an old mass movement under such conditions, the surface and subsurface topographies can differ, and it is the latter which can to some extent control the subsurface flow (Freer et al., 1997). This hypothesis is supported by the frequent occurrence of seepage in this area. The lower water retention and water circulation characterised of the soils in this part of the catchment (Navas et al., 2008), which is a result of intensive past agricultural practices, could also influence the soil saturation pattern. However, more detailed field studies should be carried out to test such hypothesis.

\subsection{Seasonal dynamics of runoff contributing areas}

\section{Infiltration excess runoff areas}

Areas prone to infiltration excess runoff are usually associated to areas with sparse vegetation, and degraded soils (Musgrave \& Holtan, 1964). Previous analysis of the relationships between suspended sediment concentrations and discharge at the outlet of 
the catchment suggested that the main contributing areas for infiltration excess runoff were associated to the main sediment sources areas (Lana-Renault \& Regüés, 2009) and correspond to i) the bare sections of the taluses flanking the main stream; ii) the patches of land affected by severe sheet-wash erosion, associated to former cultivated fields; and iii) the unpaved and deteriorated road on the north-facing slope. The total size of these areas was estimated in 7 ha, i.e., $2.44 \%$ of the catchment (table 2 ) and assumed to be constant in time. A principal reason for this assumption is that the flysch outcrops do not show the strong seasonal variations in terms of infiltration capacity that have been reported for other lithologies, including the clayey or marly lithologies in badland areas (Regüés \& Gallart, 2004; Nadal-Romero and Regüés, 2010; Regüés et al., 2012). Variations in rainfall intensity can introduce variability in the infiltration capacity of these areas and hence modify the extent for infiltration excess runoff. However, due to their limited size and the lack of information about these variations, we follow the approach of Bestson (1964), who pointed out that, variations of infiltration excess runoff areas under normal conditions are negligible, and consider 7 ha to be the potential maximum area for infiltration excess runoff.

\section{Saturation excess runoff areas}

Saturated areas occur where the topography causes the groundwater to the rise to the surface, usually at convergent down slope locations (Dunne \& Black, 1970; Dunne et al., 1975), or where soils properties (e.g., a reduction of soil hydraulic conductivity with depth) favour the development of a perched saturated layer (Gaillard et al., 1995). In the Arnás catchment, the saturated areas occur at down-slope locations, especially on the north facing slope over concave and flatter areas associated with old mass movements and are usually covered by herbaceous vegetation. 
In contrast to infiltration excess areas, the saturation excess areas were characterized by a marked spatial dynamics, associated to catchment wetness conditions. Figure 7 shows the spatial distribution of both saturation excess and infiltration excess runoff contributing areas, from dry (stream discharge of $0.81 \mathrm{~s}^{-1} \mathrm{~km}^{-2}$ ) to wetter conditions (stream discharge of $37.51 \mathrm{~s} \mathrm{~s}^{-1} \mathrm{~km}^{-2}$ ). The location of saturated areas, in the lowest valley of the catchment, suggests that most can potentially contribute to runoff. As the four surveys were carried out when the catchment was in hydrological equilibrium (i.e., at leas 36 hours after a flood event), the discharge recorded during the surveys can be considered as base flow discharge. The base flow value observed during the wettest survey is within the centile 90 of the base flow discharge series over the study period, indicating that the four surveys constitute a representative range of catchment wetness conditions. When the catchment was dry (Figure 7a), few saturated areas were evident, suggesting that under these conditions only those areas prone to infiltration excess runoff potentially contributed to the hydrological response of the catchment. The limited extent of these areas $(2.44 \%$ of the catchment) explains that event runoff coefficients observed under these conditions were very low, usually below 0.03 (LanaRenault et al., 2007). As the catchment became wetter, saturated areas appeared, especially over the bottom valley of the catchment. Their spatial distribution under wettest conditions (Figure 7d) was closely associated to the spatial distribution of the topographic index (see Figure 1); however, the pattern was very patchy, particularly on the north-facing slope. Similar to the results reported by Latron and Gallart (1997) for a catchment in the eastern Pyrenees, the patchiness of the saturated areas was more evident during the transition periods (Figure $7 \mathrm{~b}, \mathrm{c}$ ). This contrasts with typical reports for small temperate catchments, where saturation is detected in one main area close to the main stream, which expands and contracts according to catchment wetness condition 
(Dunne et al., 1975; Myrabo, 1986). Table 2 shows that the number of saturated areas and their mean size increases progressively as the catchment becomes wetter from 9 to 39, and 164 to $1297 \mathrm{~m}^{2}$, respectively. However, for the wettest conditions, the number of areas decreases to 35 and their size increases significantly, from 1297 to $4753 \mathrm{~m}^{2}$. This shift is the result of an increasing connectivity of saturated areas with increasing moisture conditions, suggesting a greater contribution to runoff and a significant effect on the hydrological response at the outlet of the catchment. The spread pattern of saturated areas has been usually explained by local factors. Latron \& Gallart (2007) related the patterns to the terrace topography, which locally leads to a rapid decrease of soil hydraulic conductivity with depth. In the Arnás catchment, the construction of small terraces and artificial drainage canals associated to past agricultural practices created discontinuities in local topography; abandonment of such areas the associated deterioration and obstruction of the drainage canals may favour saturation. Agricultural practices also modified soil properties; Seeger (2001) reported that the hydraulic conductivity of most soils in the catchment tended to decrease with depth, and that some areas of the bottom valley were characterised by a very low infiltration capacity $(5 \mathrm{~mm}$ $\left.\mathrm{h}^{-1}\right)$.

The saturated area varies from $0.05 \%$ to almost $6 \%$ of the catchment area, which is a range is similar to that reported by Latron \& Gallart (2007) for sub-Mediterranean conditions in the eastern Pyrenees, but contrasts with results reported for more humid areas (Dunne et al., 1975; Ambroise, 1986). As shown by Latron and Gallart (2007, saturation in humid areas is greater (1-40\% of the catchment) and usually shows a smaller range of variation, independently of the size of the catchments. Although the number of surveys undertaken was small, a consistent relationship was observed between the extent of saturated areas and the baseflow discharge (Figure 8), suggesting 
that the extent of saturated areas is a good indicator of catchment wetness conditions. Such relationship has been reported in both humid (Cappus, 1960; Dunne et al., 1975; Taylor, 1982; Ambroise, 1986) and Mediterranean areas (Latron \& Gallart, 2007). However, as notedt by Latron \& Gallart (2007), the regression curve that fits the relationship between the extent of saturated areas and the base flow discharge differs from one catchment to the other according to catchment topography, in particular, on the presence or absence of a confined valley bottom which limits saturation expansion for higher discharges. In the Arnás catchment, this relationship seems to be linear and could be explained by the spread pattern of the saturated areas, as has been suggested by Latron \& Gallart (2007) for the Can Vila catchment.

\subsection{Relation between the water table and the stream flow discharge}

The relationship between daily discharge e at the outlet of the catchment and water table at locations 7,8 and 9 is shown in Figure 9. The exponential relationship typically observed in other areas (e.g. Seibert et al., 2003; Latron \& Gallart, 2008; Haughts \& Meerveld, 2011) was not so evident here mainly in the present study, mainly because soil saturation can be associated with very low stream discharge values (around $1 \mathrm{I} \mathrm{s}^{-1} \mathrm{~km}^{-2}$ ). For instance, at location 9 (Figure $9 \mathrm{C}$ ), the transition from dry conditions (water table depth $>1.25 \mathrm{~m}$ from the soil surface) to almost soil saturated conditions (water table depth $<0.5 \mathrm{~m}$ from the soil surface) was rapid, as indicated by the scarcity of black dots between those two values. This is also evident in Figure 3, which shows that a change from dry to saturated conditions at this location usually occurred over a period less than one month. As a result, the correlation between stream flow discharge and the water table at location 9 under wetting-up conditions was not statistically significant $(R=-0.07, ; p>0.05)$. The relationship improved $(R=0.74 ; p<0.01)$ 
during drying-down period (white dots in Figure 9C), as the water table was progressively drawn down and reacted to rainfall events, as did the stream flow discharge. This pattern was also evident at location 7 , where groundwater recharge and the rise of the water table were very rapid (Figure 3). The water table dried down progressively (white dots in Figure 9A), as did the stream flow discharge, although there was some variability associated with the general trend $(R=0.69 ; p<0.01)$. A statistically significant correlation was found between the stream flow and the water table at location 8, for both the wetting-up and drying-down periods $(R=0.23$ and $R=0.49$ respectively; $p<0.01)$, suggesting a slightly better connection at this location between groundwater and the stream flow discharge.

Figure 9 also shows that relatively high discharges $\left(>10 \mathrm{I} \mathrm{s}^{-1} \mathrm{~km}^{-2}\right)$ sometimes occurred when water table was low at the three locations. This happened during rainy days, in the wetting-up period, suggesting that the stream flow response of the catchment was generated by the occurrence of runoff generation mechanisms other than saturation excess runoff associated with the rise of water table. Lana-Renault et al. (2007) demonstrated the occurrence of flood events when piezometers were dry; these events associated to infiltration excess runoff over localised areas in response to intense rainfall events. In contrasts, we observed low discharges were under soil saturation conditions, especially at location 7 and 8 , This occurred at beginning of the drying-down period, when discharge was already at a low level, but the water table was still high at some locations (see Figure 3), illustrating a degree of disconnect between stream flow and groundwater 
To further investigate the spatial and temporal variability of the water table response within the catchment, for locations 8 and 9, we compared the relationships between the water table depth and stream flow response during several flood events. Water table at location 7 was not considered because it did not show any fluctuation during the analyzed flood event. Figure 10 shows that location 9 reached saturation only when the water table at the beginning of the flood event was $<1 \mathrm{~m}$ in depth from the soil surface. For drier, there was little reaction of the water table, which rose by only a few centimetres. A similar water table at location 8 reached the soil surface under dry conditions (e.g. the whater table at the beginning of the flood event was $-1.5 \mathrm{~m}$ on 2 November) and very dry conditions (e.g. $-1.85 \mathrm{~m}$ on 15 October). For the other events, the water table at this location showed greater fluctuations, with increases in water table heigh of up to $30 \mathrm{~cm}$. The local slope gradiente at location $8\left(12 \mathrm{~m} \mathrm{~m}^{-1}\right)$, much steeper that at location $9\left(7 \mathrm{~m} \mathrm{~m}^{-1}\right)$, may partly explain the more responsive behaviour o the water table at that location.

Figure 10 also indicates that for the analyzed flood events, the peak of the water table was always reached following the peak of stream flow. This was observed at all monitored locations, suggesting a potentially important contribution of surface runoff to the catchment stream flow response. Time lags between the water table and stream flow peaks were calculated for locations 8 and 9. At each location, the time lag tended to decrease as the catchment became wetter, although the relationship was not statistically significant $(R>0.4$; $p>0.05$ ). The water table at location 8 reacted more rapidly (average time lag 1 h $37 \mathrm{~min}$ ), whereas at location 9, the water table peak was reached on average, $4 \mathrm{~h} 12$ min after the peak flow discharge. The different behaviours of the water 
table between location 8 and 9 were not related to the position on the hillslope, as reported in other studies (Seibert et al., 2003; Haughts \& Meerveld, 2011) because each piezometer was located at similar distance from the main stream (see Fig 6a). Rather, the more rapid response of water table at location 8 may have been related to the local topography (e.g. local slope gradient, different subsurface topography) and/or soil properties (e.g. preferential flow pathways). In this sense, it is necessary to carry out more detailed reasearch to relate the particular response of waster table at location 8 with local site characteristics.

\section{Discussion and conclusions}

In this study the temporal and spatial dynamics of water table was investigated in a small Mediterrenean mountain catchment in the Spanish Pyrenees. The results showed that water table followed a marked seasonal evolution involving a drying-down period of the water table from the end of the spring (associated to an increasing evapotranpirative demand) a wetting-up period commencing with the first autumn rainfalls, and a wet period during winter and spring, when water table was closed to the soil surface at all study locations. However, the length of these periods varied substantially among years, depending on the rainfall and evapotranpiration characteristics. The water table fluctuations also varied substantially among locations. This spatial variability was particularly important during the recharge of the ground water reserves and relatively homogeneous when the reserves saturated and drawing down. Topography (drainage area and slope) partially explained the degree of saturation observed at each location although other factors (including soil properties, local topography and geomorphology) may also control water table fluctuations and the saturation pattern at specific locations. 
Infiltration excess runoff areas were identified within the catchment and were associated to previous land use because most were located in the former cultivated fields affected by severe sheet-wash erosion on the south facing slope. Saturation excess runoff areas were also identified and their spatial dynamics described. The distribution of these areas within the catchment was partly explained by topography as they tended to appear over flat areas at the base of the slopes. However, these areas were scattered throughout the catchment, suggesting the influence of factors others than topography, including changes in local topography (through the construction of small terraces and drainage canals) and soil properties (e.g. a decrease of soil hydraulic conductivity with depth), both which are a result of past agricultural activities.

It is noteworthy that the degree of the saturated area in the Arnás catchment varied by two orders of magnitude, whereas in more humid environments, the variability is lower. In drier environments, such as the Mediterranean region, the transition (drying-down, wetting up) periods last longer, explaining the wider range of catchment moisture status. Under such conditions, factors such as local topography, vegetation or soil properties become importance in explaining soil moisture (Grayson et al., 1997) and consequently saturation patterns, and results in a heterogeneous spatial distribution of saturated areas. Situations as this need to be considered when representing saturation patterns based only on topographic indices, especially those derived from conventional Digital Elevation Models which do not capture the local topography. In addition, failure to consider the effect of soil properties and vegetation patterns on soil moisture and the groundwater dynamics might also be misleading, especially in dry and human disturbed environments such as Mediterranean mountains. Field surveys of the spatial distribution of saturated areas, carried our under different catchment wetness conditions, revealed that increasing wetness condition favoured hydrological connectivity. Study of the of 
the hydrological connectivity is recognized as a key issue in the understanding of stream flow response (Bracken \& Croke, 1997) and efforts have been made to measured it in the field and incorporate it into simulations models; in this context, field surveys such as the one undertaken here should be encouraged.

The relation between water table levels and stream flow was quite weak, especially during the wetting up period, suggesting little connection between ground water and the hydrological response, at least at some locations. This raises the question whether the steady state assumption (that groundwater storage and runoff can be described as a succession of steady state flow conditions), which is widespread in conceptual modelling, is appropriate in this kind of environment. Reports of non-steady behaviours in other areas (e.g., Siebert et al., 2003; Latron \& Gallart, 2008; Anderson et al., 2010; Haught \& Meerveld, 2011) have suggested the need to relax the assumption and consider the catchment as a spatially organized system of different hydrological units. The weak relationship between water table and discharge also suggest the occurrence of runoff generation process other than saturation due to a rise in the water table. This confirms the hypothesis that catchment is complex in environments such as the Mediterranean mountains, because the stream flow discharge is generated by a combination of different runoff generation processes (infiltration excess, saturation excess runoff processes and subsurface flow), depending on catchment moisture condition and rainfall characteristics (depth and intensity). Such complexity is related to marked climatic seasonality and long wetting-up and drying-down transition periods, but also to the landscape, which is very heterogeneous in terms of soils, topography and vegetation, and the intensity of past human practices. This study illustrates that to understand and predict the hydrological response of catchments under Mediterranean 
conditions, it is important to capture the temporal and spatial variability of the catchment water pathways.

\section{Acknowledgements}

This research was conducted with the support of INDICA (grant no. CGL2011-27753C02-01) project financed by the Spanish Commission of Economy and Competitiveness. The authors also acknowledge support from RESEL (the Spanish Ministry of the Environment). N. Lana-Renault was the recipient of a research contract (Human resources mobility, National Program I+D+I 2008-2011) and J. Latron the recipient of a research contract (Ramón y Cajal programme), both funded by the Spanish Ministry of Sciences and Innovation. programme). Support provided by E. NadalRomero and M.L. Rodríguez Blanco during fieldwork is acknowledged.

\section{References}

Ambroise, B. (1986). Rôle hydrologique des surfaces saturées en eau dans le bassin du Ringelbach à Soultzeren (Hautes Vosges, France). En: O. Rentz, J. Streith, L. Zilliox (eds.), 1er Colloque scientiphique des universités du Rhin Supérieur "Recherches sur l'environnement dans la région". Université Louis Pasteur-Conseil d’Europe, Strasbourg, 620-630.

Ambroise, B. (2004). Variable "active" versus "contributing" areas or periods: a necessary distinction. Hydrological Processes, 18: 1149-1155.

Anderson, A.E., Weiler, M., Alila, Y., Hudson, R.O., (2010). Piezometric response in zones of a watershed with lateral preferential flow as a first-order control on subsurface flow. Hydrological Processes, 24: 2237-2247. DOI: 10.1002/hyp.7662.

Arnáez, J., Lasanta, T., Errea, M.P., Ortigosa, L.M. (2011). Land abandonment, landscape evolution and soil degradation in a Spanish Mediterranean Mountains: the case of Camero Viejo. Land Degradation and Development, 22(6): 537-550. DOI: $10.1002 / 1 \mathrm{dr} .1032$. 
Bachmair S. Weiler M. 2012. Hillslope characteristics as controls of subsurface flow variability. Hydrology and Earth System Sciences 16: 3699-3715.

Betson, R.P., 1964. What is Watershed Runoff? Journal of Geophysical Research 69 (8), 1541-1552.

Betson, R.P. \& Marius, J.B. (1969). Source areas of strom runoff. Water Resources Research, 5: 574-582.

Bracken, L.J., Croke, J. (2007). The concept of hydrological connectivity and its contribution to understanding runoff-dominated geomorphic systems. Hydrological Processes, 21: 1749-1763. DOI: 10.1002/hyp.6313.

Cappus, P., 1960. Bassin expérimental d'Alrance. Étude des lois de l'écoulement. Application au calcul et à la prévision des débits. La Houille Blanche A, 493-520.

Cosandey, C., de Oliveira, M. (1996). Surfaces saturées, surfaces contributives: localisation et extension dans l'espace du bassin versant. Hydrological Sciences Bulletin- des Sciences Hydrologiques, 41(5): 751-761.

Dripps, W.R., Bradbury, K.R. (2010). The spatial and temporal variability of groundwater recharge in a forested basin in northern Wisconsin. Hydrological Processes, 24: 383-392. 10.1002/hyp.7497.

Dunne, T., Black, R.D., 1970. Partial Area Contributions to Storm Runoff in a Small New England Watershed. Water Resources Research 6 (5), 1296-1311.

Dunne, T., Moore, T.R., Taylor, C.H. (1975). Recognition and prediction of runoffproducing zones in humid regions. Hydrological Sciences -Bulletin- des Sciences Hydrologiques, 20(3): 305-327.

Fanning R.J., Jaakkola J., Wilkinson M.T., Hetherington E.D. 2000. Hydrologic response off soils to precipitation ata Arnation Creek, Brithis Columbia, Canada. Water Resource Research, 36 : 1481-1494.

Freer J, McDonnell J, Beven KJ, Brammer D, Burns D, Hooper RP, Kendal C. 1997. Topographic Controls on Subsurface Storm Flow at the Hillslope Scale for Two Hydrologically Distinct Small Catchments. Hydrological Processes 11: 1347-1352. 
Gaillard, E., Lavabre, J., Isbérie, C., Normand, M., 1995. Etat hydrique d'une parcelle et écoulements dans un petit bassin versant du massif cristallin des Maures. Hydrogéologie 4, 41-48

García-Ruiz, J.M, Lana-Renault, N., 2011. Hydrological and erosive consequences of farmland abandonment in Europe, with special reference to the Mediterranean region -a review. Agriculture, Ecosystems and Environment 140: 317-338.

Grayson, R. B., Western, A. W., Chiew, F. H. S., Blöschl, G., 1997. Preferred states in spatial soil moisture patterns: Local and nonlocal controls, Water Resources Research 33 (12), 2897-2908.

Grésillon, J.M., Taha, A., 1998. Les zones saturées contributives en climat méditerranéen: condition d'apparition et influence sur les crues. Hydrological Sciences Bulletin- des Sciences Hydrologiques 43 (2), 267-282.

Hargreaves, G.H., Samani, Z.A., 1985. Reference crop evapotranspiration from temperature. Applied Engineering in Agriculture 1(2), 96-99.

Haughts, D.R, Meerveld, H.J. 2011. Spatial variation in transient water table responses: differences between an upper and lower hillslope zone. Hydrological processes, 25: DOI: $10.1002 /$ hyp. 8354 .

Kirkby, M.J., 1975. Hydrograph modelling strategies. In: Peel, R., Chisholm, M., Hagget, P. (Eds.), Processes in Physical and Human Geography, Heinemann, London, pp. 69-90.

Lana-Renault, N., 2011. El efecto de los cambios de cubierta vegetal en la respuesta hidrológica y sedimentológica de áreas de montaña: la cuenca experimental de Arnás, Pirineo Central. Consejo de Protección de la Naturaleza de Aragón , Zaragoza, 189 pp.

Lana-Renault, N., Regüés, D., 2009. Seasonal patterns of suspended sediment transport in an abandoned farmland catchment in the Central Spanish Pyrenees. Earth Surface Processes and Landforms 34, 1291-1301.

Lana-Renault N, Latron J, Regüés D. 2007. Streamflow response and water-table dynamics in a sub-Mediterranean research catchment (Central Pyrenees). Journal of Hydrology 347: 497-507. 
Latron, J., Gallart, F., 2007. Seasonal dynamics of runoff-contributing areas in a small mediterranean research catchment (Vallcebre, Eastern Pyrenees). Journal of Hydrology 335 (1-2), 194-206.

Latron, J., Gallart, G., 2008. Runoff generation processes in a small Mediterranean research catchment (Vallcebre, Eastern Pyrenees). Journal of Hydrology 358, 206-220.

Latron, J., Llorens, P., Gallart., F., 2009. The Hydrology of Mediterranean Mountain Areas. Geography Compass 3/6, 2045-2064.

Linde, N., Revil, A., Bolève, A., Dagès, C., Castermant, J., Suski, B., Voltz, M., 2007. Estimation of the water table throughout a catchment using self-potential and piezometric data in a Bayesian framework. Journal of Hydrology 334 (1-2), 88-98.

Martínez-Fernández, J., Ceballos Barbancho, A., Hernández Santana, V., Casado Ledesma, S., Morán Tejeda, C. 2005. Procesos hidrológicos en una cuenca forestal del Sistema Central: cuenca experimental de Rinconada. Cuadernos de Investigación Geográfica, 31: 7-25.

Molénat, M., Gascuel-Odoux, C., Davy, P., Durand, P., 2005. How to model shallow water-table depth variations: the case of the Kervidy-Naizin catchment, France. Hydrological Processes 19 (4), 901-920.

Musgrave, G.W., Holtan, H.N. (1964). Infiltration. In: V.T. Chow (ed.), Handbook of Applied Hydrology, McGraw-Hill, New York, 12.10-12.30

Myrabo, S., 1986. Runoff studies in small catchments. Nordic Hydrology 17 335-346.

Nadal-Romero, E., Regüés, D. 2010. Geomorphological dynamics of sub-humid mountain badland areas: weathering, hydrological and suspended sediment transport processes. A case of study in the Araguás catchment (Central Pyrenees), and implications for altered hydro-climatic regimes. Progress of physical geography, 34(2), 123-150.

Navas, N., Machín, J., Beguería, S., López-Vicente, M., Gaspar, L. (2008). Soil properties and physiographic factors controlling the natural vegetation re-growth in a disturbed catchment of the Central Spanish Pyrenees. Agroforestry systems, 72: 173185. DOI 10.1007/s10457-007-9085-2.

O'Loughlin, E.M., 1981. Saturation regions in catchments and their relations to soil and topographic properties. Journal of Hydrology 53, 229-246 
Penna D., Brocca L., Borga M., Dalla F.G. 2013. Soil moisture temporal stability at different depths on two alpine hillslope during wet and dry periods. Journal of Hydrology 477, 55-71.

Peters, E., Freer, J., Aulenbach, B.T., 2003. Hydrological Dynamics of the Panola Mountain Research Watershed, Georgia. Ground Water 41 (7), 973-988.

Piñol, J., Beven, K., Freer, J., 1997. Modelling the hydrological response of Mediterranean catchments, Prades, Catalonia. The use of distributed models as aids to hypothesis formulation. Hydrological Processes 11 (9), 1287-1306.

Regüés, D., Gallart, F. 2004. Seasonal patterns of runoff and erosion responses to simulated rainfall in a badland area in mediterranean mountain conditions (Vallcebre, Southeastern Pyrenees). Earth Surface Processes and Landforms, 29: 755-767.

Regüés, D., Serrano-Muela, P, Nadal-Romero, E., Lana-Renault. N. 2012. Análisis de la variabilidad de la infiltración en un gradiente de degradación de usos del suelo en el Pirineo Central. Cuaternario y Geomorfología 26(1-2), 9-28.

Riderer M., Kollegger A., Fischer BMC., Seiberg J. 2012. Sensing with Boots and Trousers- Qualitative Field Observations of Shallow Soil Moisture Patterns. Hydrological Processes 26: 4112-4120.

Seeger, M. 2001. Boden und Bodenwasserhaushalt als Infikatoren der Landdergradierung auf extensivierten Nutzflächen in Aragón/Spanien. Freiburger Geographische Hefte 63, Freiburg, 184 p.

Seibert, J., Bishop, K., Rodhe, A., McDonnell, J.J. 2003. Groundwater dynamics along a hillslope: A test of the steady state hypothesis. Water Resources Research, 39: 1014. doi:10.1029/2002WR001404.

Serrano-Muela M.P., Lana-Renault, N., Nadal-Romero, E., Regüés D., Latron, J., Martí-Bono C., García-Ruiz J.M. 2008. Forest and their hydrological effects in Mediterranean mountains: The case of the Spanish Pyrenees. Mountain Research and Development 28: 279-285.

Taylor, C.H. (1982). The effect on storm runoff response of seasonal variations in contributing zones in small watersheds. Nordic Hydrology, 13: 165-182. 
Table 1. Annual rainfall $(\mathrm{P})$, rainfall at soil saturation $\left(\mathrm{P}_{\text {sat }}\right)$, runoff coefficient $(\mathrm{RC})$, and length of the saturation period (in \% of days per year) measured at each location. The average saturation period (in \% and $\mathrm{n}$ number of days per year) is also indicated.

\begin{tabular}{rrrrrrrrrrr}
\hline Year & $\begin{array}{c}\mathrm{P} \\
(\mathrm{mm})\end{array}$ & $\begin{array}{c}\mathrm{P}_{\text {sat }} \\
(\mathrm{mm})\end{array}$ & $\begin{array}{c}\mathrm{RC} \\
(\%)\end{array}$ & \multicolumn{1}{c}{$\begin{array}{c}\mathrm{w} 2 \\
(\%)\end{array}$} & $\begin{array}{c}\mathrm{w} 4 \\
(\%)\end{array}$ & $\begin{array}{c}\mathrm{w} 7 \\
(\%)\end{array}$ & $\begin{array}{c}\mathrm{w} 8 \\
(\%)\end{array}$ & $\begin{array}{c}\text { w9 } \\
(\%)\end{array}$ & $\begin{array}{r}\text { Average } \\
(\%)\end{array}$ & $\begin{array}{c}\text { Average } \\
\mathrm{n}\end{array}$ \\
\hline 0405 & 670 & 152 & 18 & 9 & 13 & 14 & 16 & 12 & 13 & 46 \\
0506 & 986 & 337 & 24 & 24 & 38 & 51 & 48 & 31 & 38 & 139 \\
0607 & 876 & 559 & - & 43 & - & 62 & 66 & 44 & 54 & 196 \\
0708 & 922 & 588 & 32 & 28 & 30 & 31 & 37 & 30 & 31 & 114 \\
0809 & 889 & 460 & 26 & 41 & 48 & - & 53 & - & 47 & 172 \\
0910 & 1094 & 548 & 26 & - & 54 & - & 54 & 38 & 49 & 178 \\
\hline
\end{tabular}


Table 2. Main characteristics of the 4 surveys of runoff contributing areas in the Arnás catchment. $\mathrm{Q}_{0}$ : baseflow discharge; Extent INF: contributing areas for infiltration excess runoff; Extent SAT: contributing areas for saturation excess runoff; n SAT: number of distinct contributing areas for saturation excess runoff; w4: depth to water table at location w4.

\begin{tabular}{lrrrrrrr}
\hline \multicolumn{1}{c}{ Date } & $\begin{array}{c}\mathrm{Q}_{0} \\
\left(\mathrm{ls}^{-1} \mathrm{~km}^{-2}\right)\end{array}$ & $\begin{array}{c}\text { Extent } \\
\text { INF (\%) }\end{array}$ & $\begin{array}{c}\text { Extent } \\
\text { SAT }(\%)\end{array}$ & $\begin{array}{c}\text { Total } \\
\text { extent } \\
(\%)\end{array}$ & $\begin{array}{c}\mathrm{n} \\
\text { SAT }\end{array}$ & $\begin{array}{r}\text { Mean area } \\
\text { SAT }\left(\mathrm{m}^{2}\right)\end{array}$ & $\begin{array}{r}\text { w4 } \\
(\mathrm{m})\end{array}$ \\
\hline $1^{\text {st }}$ July & 0.8 & 2.44 & 0.05 & 2.49 & 9 & 164 & -1.04 \\
$13^{\text {th }}$ May & 5.1 & 2.44 & 0.69 & 3.13 & 29 & 675 & -0.18 \\
$12^{\text {th }}$ June & 7.8 & 2.44 & 1.78 & 4.22 & 39 & 1297 & 0 \\
$13^{\text {th }}$ March & 37.5 & 2.44 & $5.86^{*}$ & 8.30 & 35 & 4753 & 0
\end{tabular}

* For technical reasons, it was not possible to map the whole surface extent of some saturated areas so we assume this corresponded to a minimum value. 


\section{Figure captions}

Figure 1. a) Location of the Arnás catchment and b) the Arnás catchment showing the topographic index $\ln (\mathrm{A} / \tan \beta)$ (Kirkby, 1975) and the sites of the main monitoring instruments.

Figure 2. Monthly mean values of rainfall, reference evapotranspiration $\left(\mathrm{ET}_{0}\right)$ and runoff for water years 1999-2008. ET 0 is calculated by the method of Hargreaves \& Samani 1985.

Figure 3. Seasonal evolution of rainfall, runoff and depth to water table at different locations, from 1st March 2005 to 30th September 2007. The lower bar shows the succession of wetting up (dark grey), wet (black) and drying down (light grey) periods.

Figure 4. Relationship between the mean daily water-table depth at locations w7, w8 and $\mathrm{w} 9$ and standard deviation.

Figure 5. Relationships between daily water table depth at locations w7, w8 and w9. White dots refer to examples of drying down periods.

Figure 6. Relationship between fraction of time each location is saturated and a) minimum distance to the main stream and b) topographic index $\ln (\mathrm{A} / \tan \beta)$ (Kirkby, 1975).

Figure 7. Dynamics of runoff contributing areas in the Arnás catchment, from dry conditions (baseflow $\left.\mathrm{Q}_{\mathrm{b}}=0.81 \mathrm{~s}^{-1} \mathrm{~km}^{2}\right)$ to wetter conditions $\left(\mathrm{Q}_{\mathrm{b}}=37.51 \mathrm{~s}^{-1} \mathrm{~km}^{2}\right)$.

Figure 8. Relationship between total extent of saturated areas observed during each survey and the baseflow discharge at the outlet of the catchment $\left(\mathrm{Q}_{\mathrm{b}}\right)$.

Figure 9. Relationship between daily stream flow discharge (Q) and water table depth at locations w7, w8 and w9. White dots refer to examples of drying down periods

Figure 10. Water table depth and stream flow discharge (Q) for selected floods at locations w8 and w9. The arrows represent the storm time progression. 
Figure 1

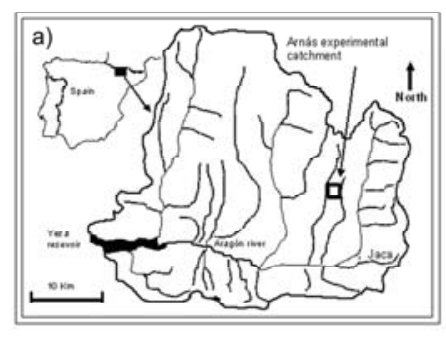

$\triangle$ pluviometer

is weather station

$\square$ gauging station

+ piezometer

$\ln (\mathbf{A} / \tan \mathbf{s})$

$\square<5$

$7.5-10$

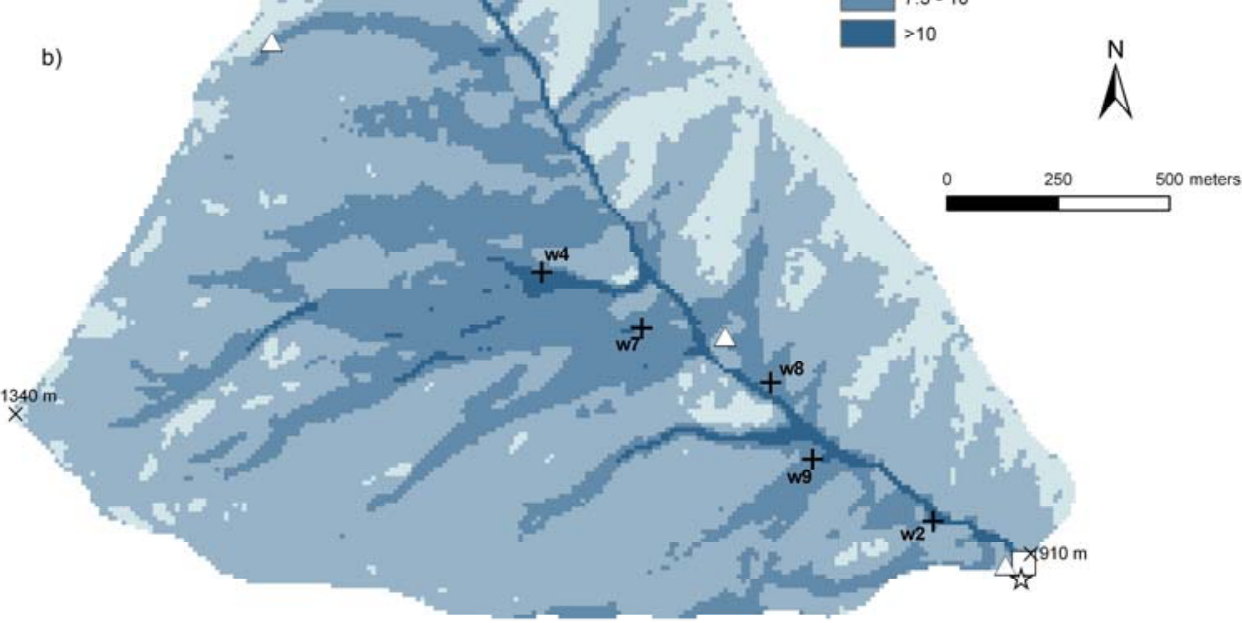


Figure 2

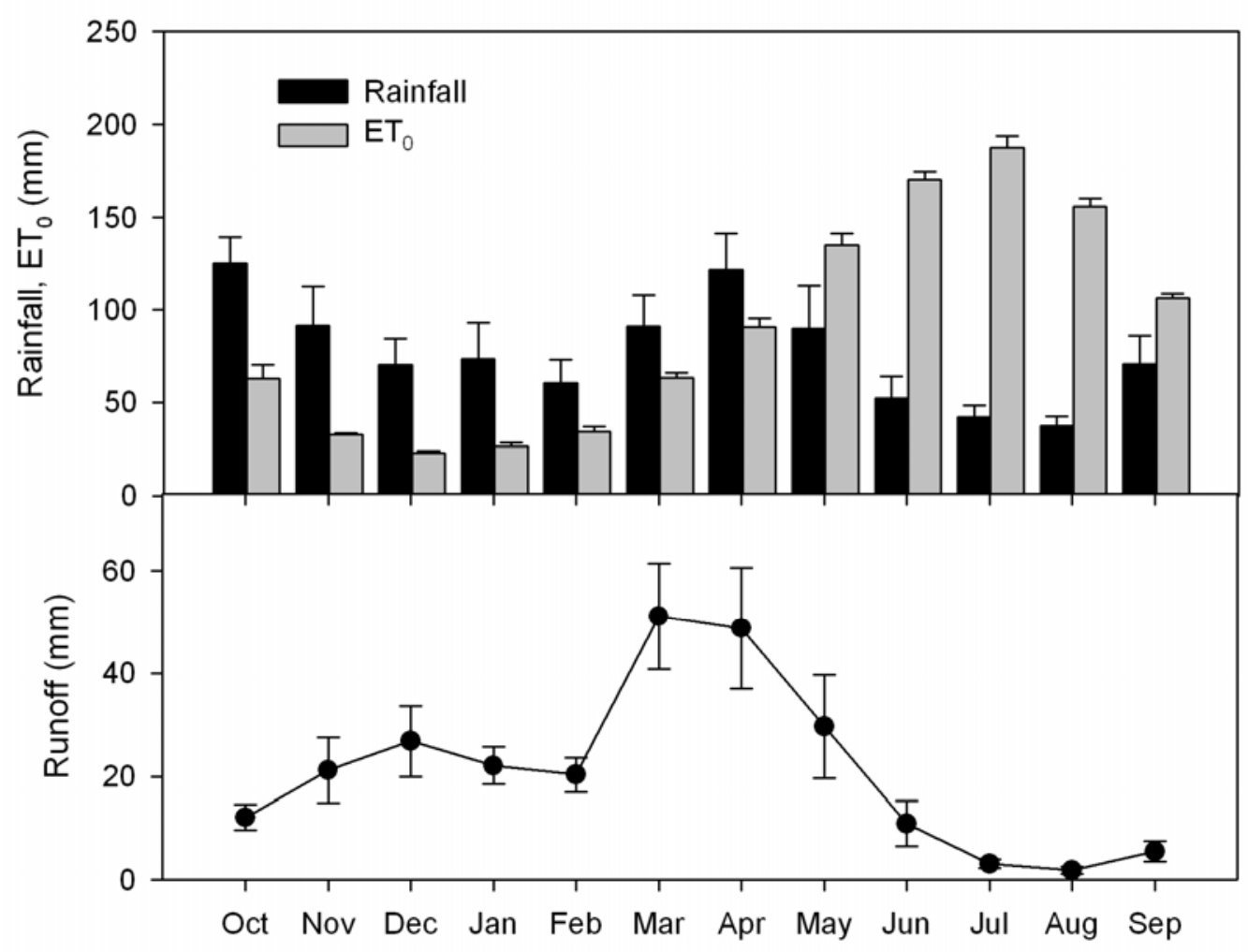


Fig 3

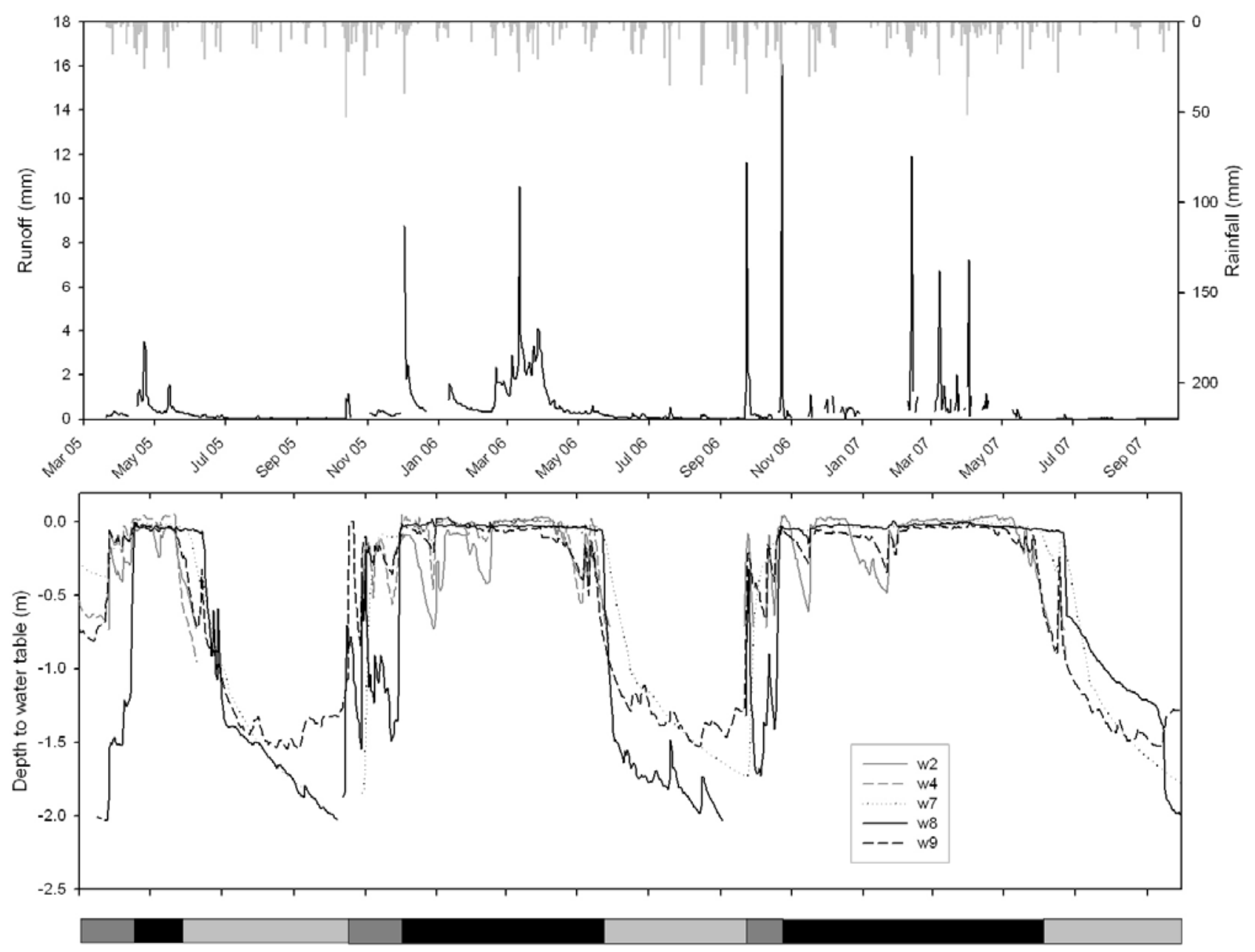


Fig 4

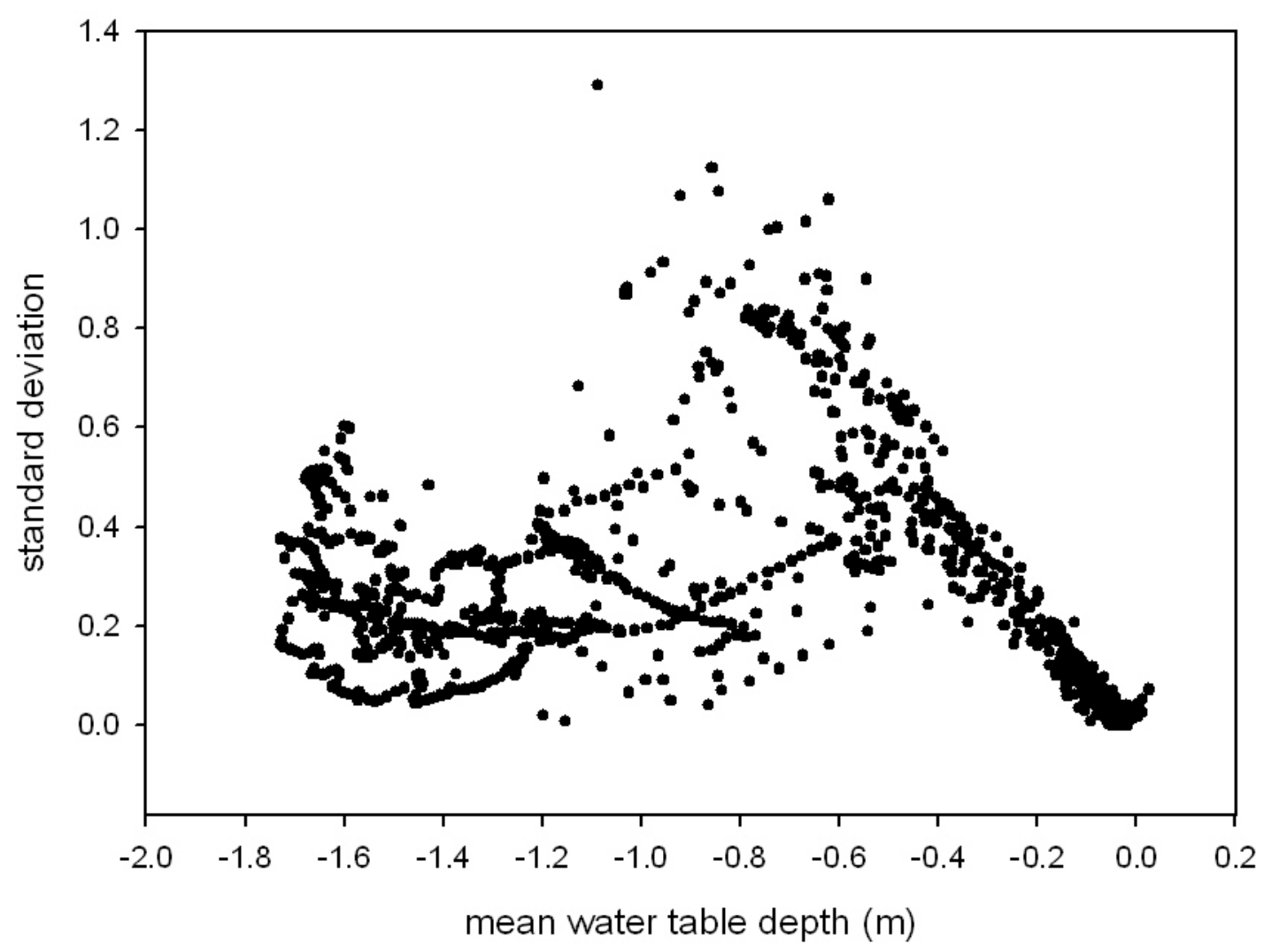


Fig 5
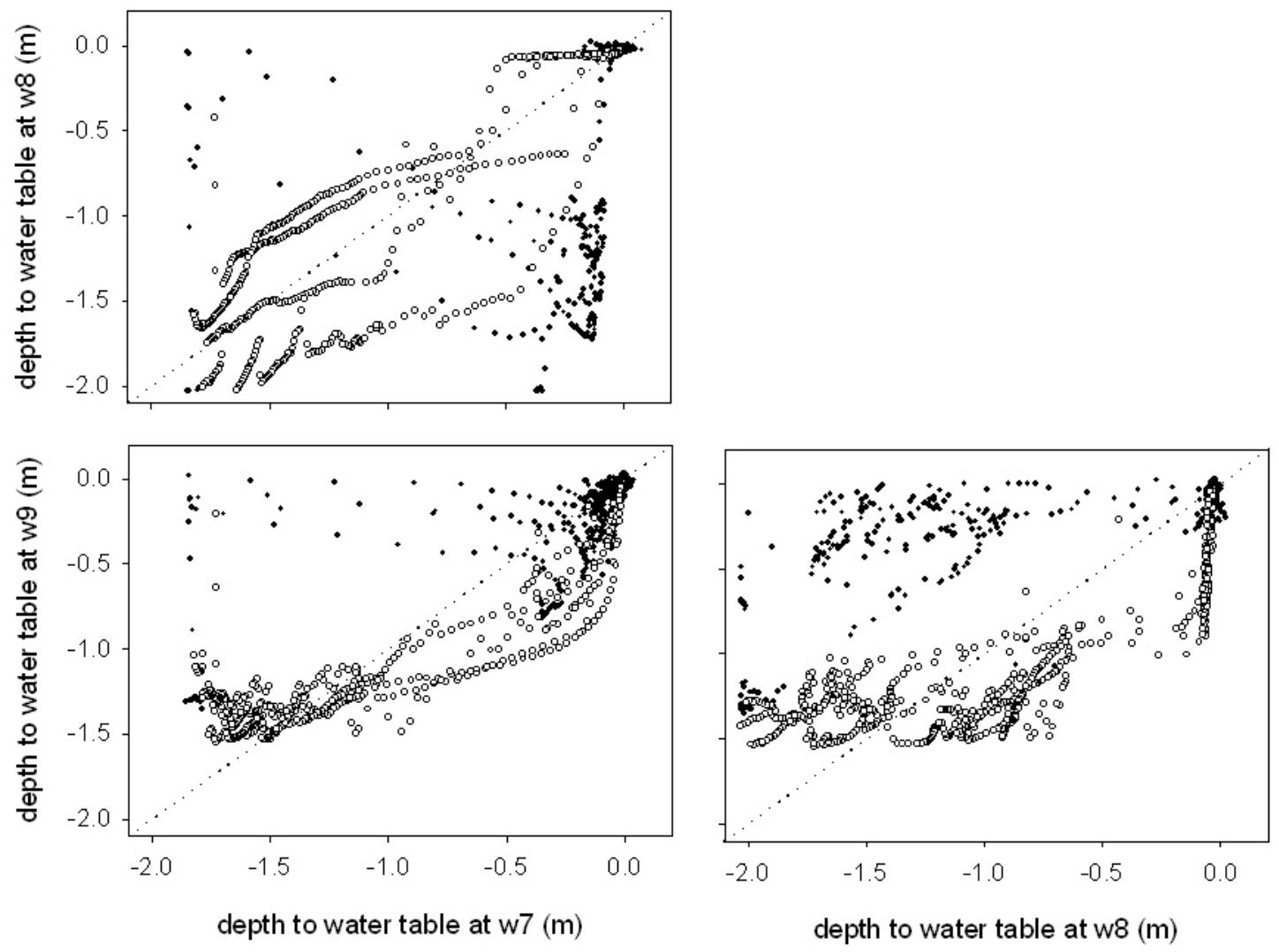
Fig 6
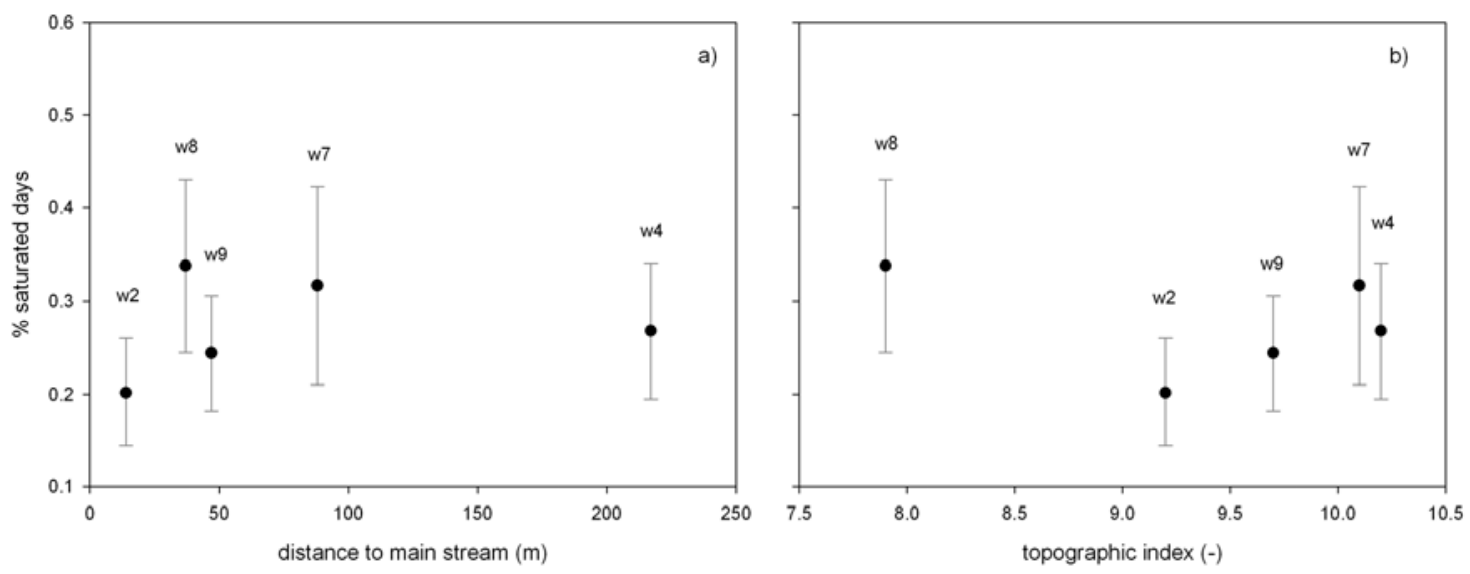
Fig 7
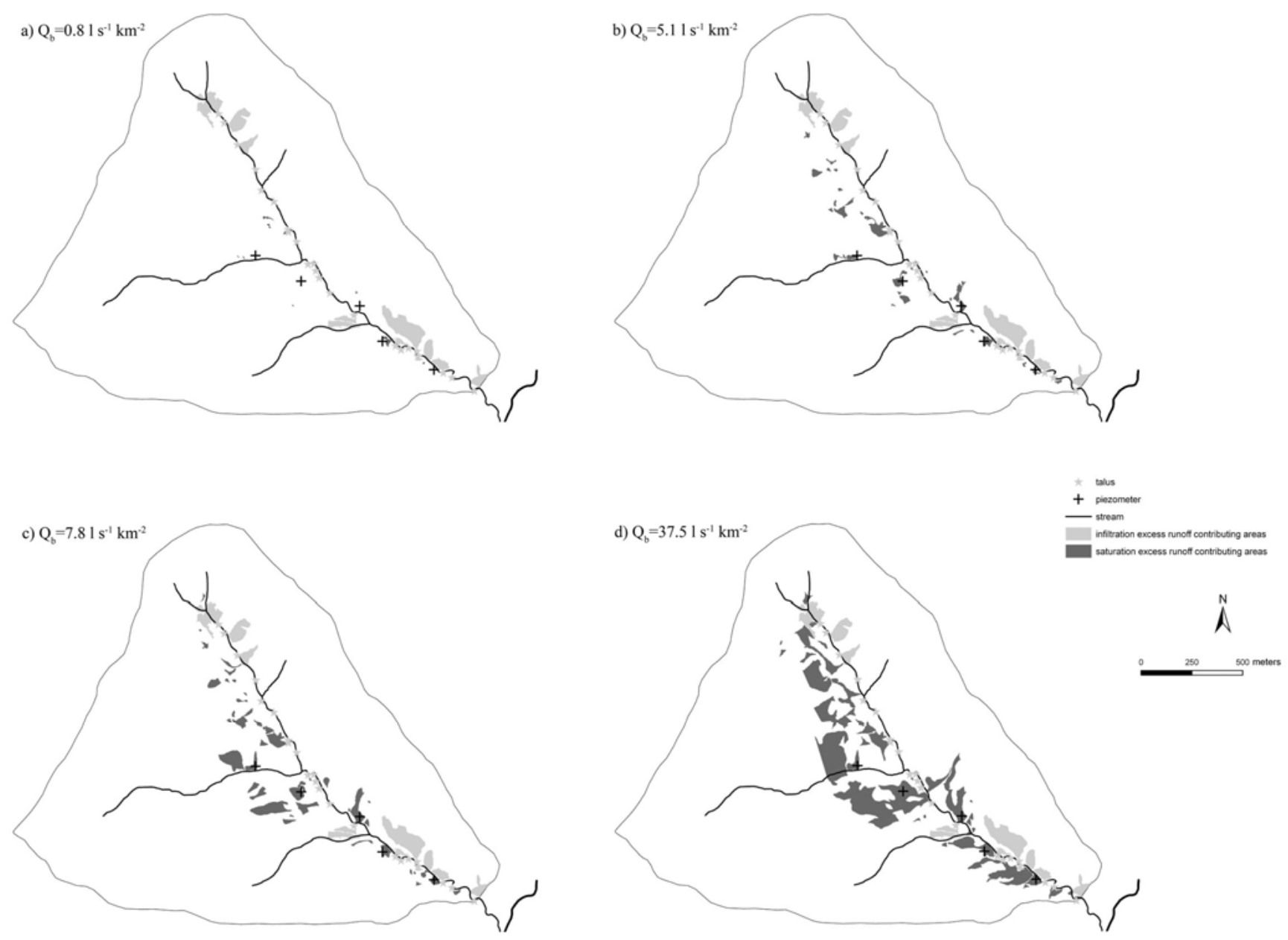
Fig 8

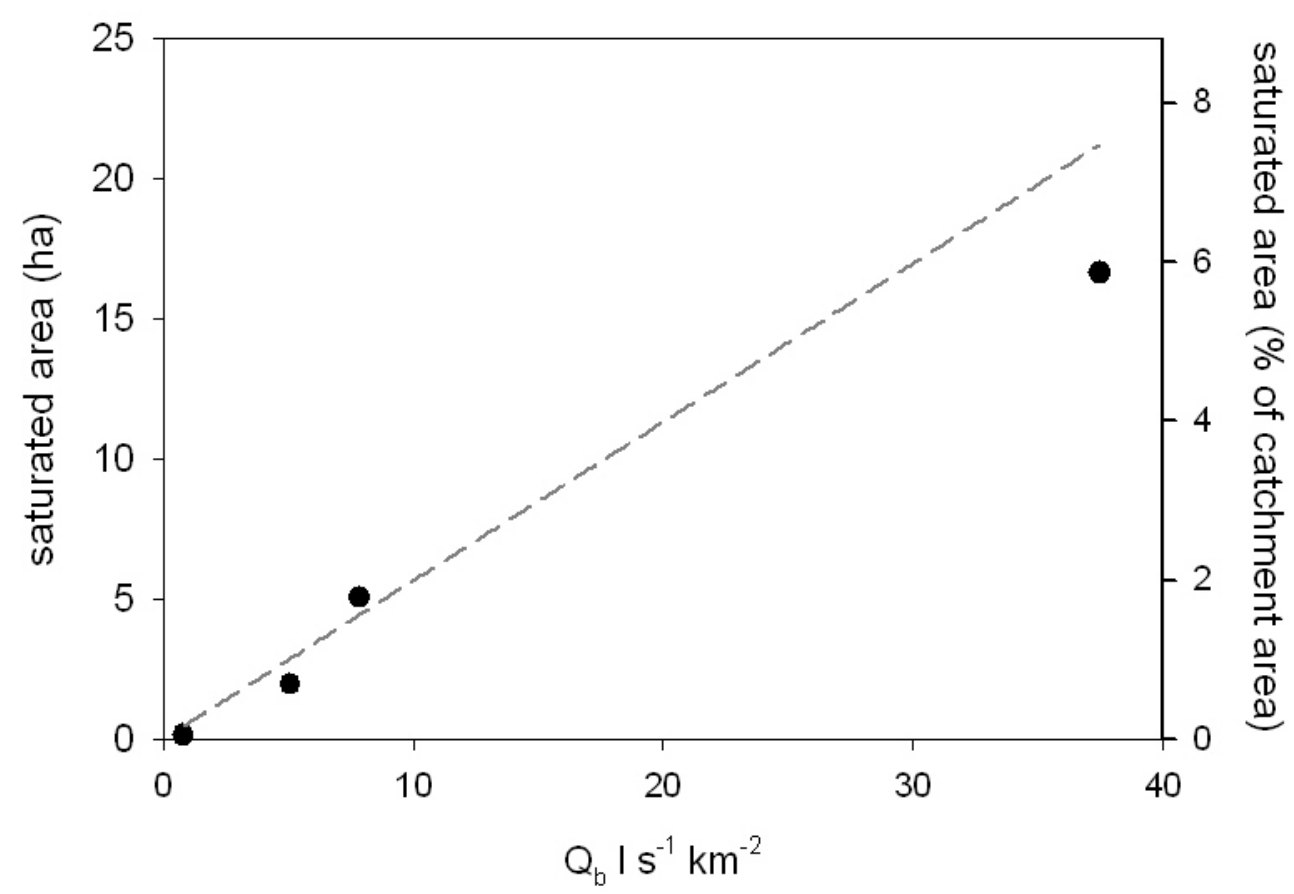


Fig 9
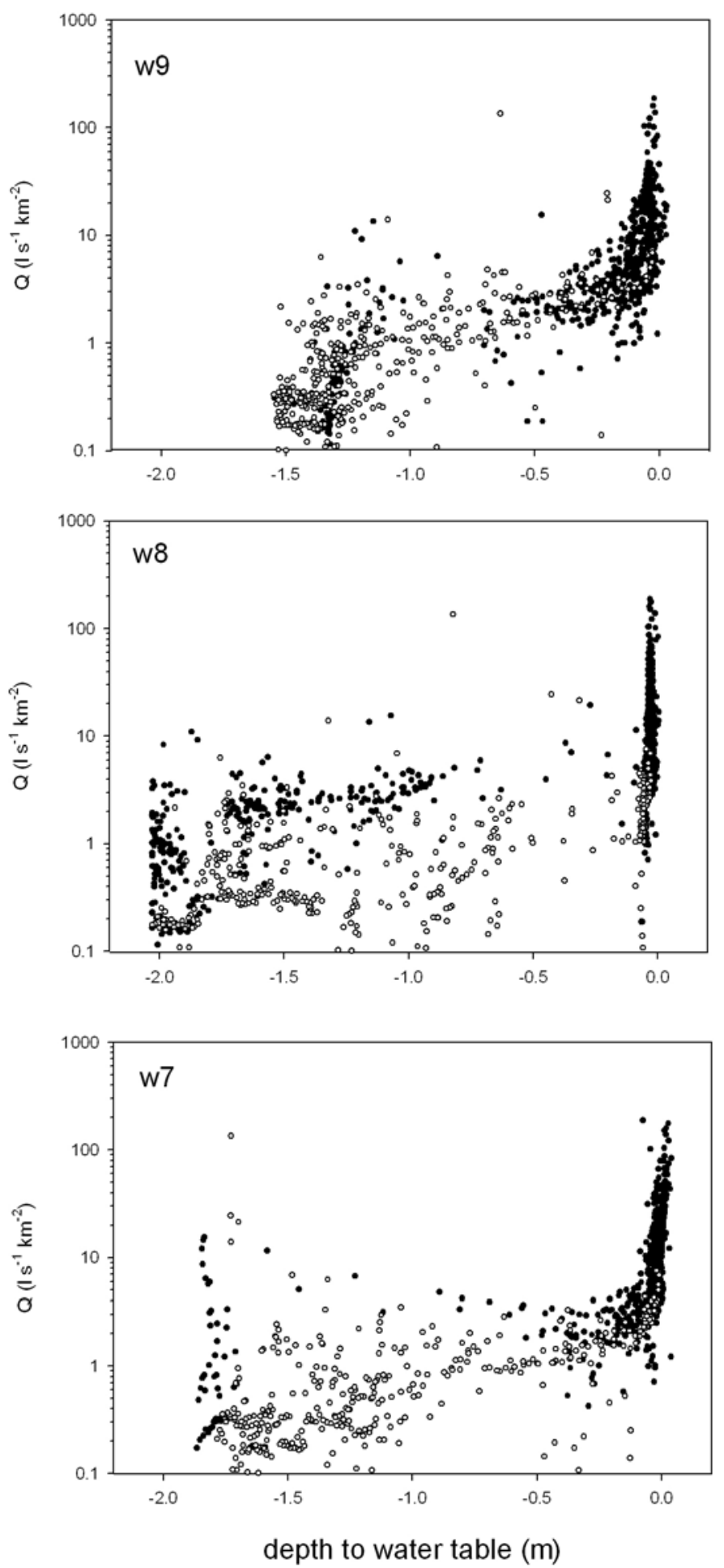
Fig 10
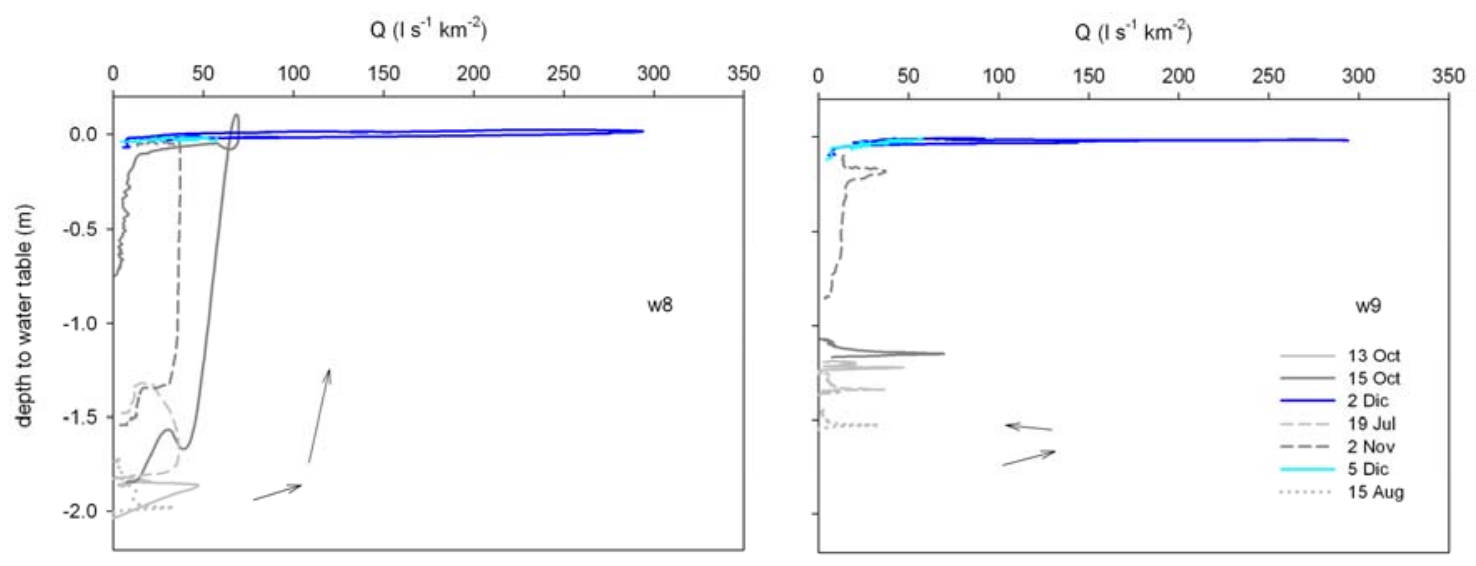